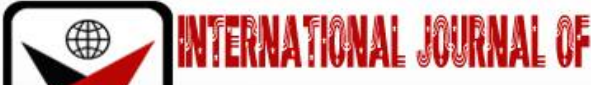

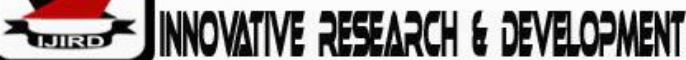

ISSN 2278-0211 (Online)

\section{Effective Policing In Contemporary Nigeria: The Nigeria Police Force}

\author{
Zanna Ibrahim Mohammed \\ CEO, Nigeria Police Academy, Wudil-Kano, Nigeria \\ Dr. Zems Mathias \\ Africa Regional Representative, University of America, Temecula, USA
}

\begin{abstract}
:
To say the least, fighting crime, social deviance, and maintaining public order /safety are two of the most important tasks of every government; our policymakers tend to have very limited information on how to achieve this goal, (Eck \& Edward, 2006). This paper attempts to identify critical issues that are germane to effective policing in contemporary Nigeria. The paper also identifies some challenges that plague the Nigeria Police Force as an institution in the present democratic settings, (Zems, 2017). In spite of awful and prevailing security challenges, the paper would identities prospects in the sustenance of effective policing in the present democratic epoch, (David \& John, 2004). To achieve this, the paper concludes with good governance concerning police reform as strategies for an effective policing in contemporary Nigeria, (Flanagan, 2008:7,). Policing refers to the profession and practice of maintaining social order and enforcing the law through the prevention, detection, and intelligence-led policing to reducing the crime and fear of crime too. As society's most visible and contacted legal agents, police officers are empowered by a governmental body, Worrall, 2002). Finally, in the paper, we focus on efforts aimed at improving the efficiency and effectiveness of the Nigeria Police Force. That's the main point of these discussions, so far most of the literature focused on the constraints to police work, (Alemika, 1999).
\end{abstract}

Keywords: Nigeria police, effectiveness, efficiency, policing, and police

\section{Introduction}

In most countries, police organizations occupy an important position in the engagement between governments and their citizens. Indeed, police around the world have a monopoly over the use of legitimate force, which gives them a special responsibility in terms of policing a Nation. Therefore, police action has to be performed according to the highest professional standards to achieve its statutory goals, (Braga \& David, 2010).

In as much as, the task of policing is a difficult one. Many countries wrestle with economic inequality, political crisis, religious and ethnic tensions that may give rise to sporadic clashes between the police and her citizenry. This is common and prominent in some countries that have challenges of banditry, kidnapping, and armed robbery activities and religiousterrorism, insurgency, and separatist strains, (Alemika \$ Chukwuma, 2000).

Consequently, work effectiveness is the key to successful operation in policing agencies or any organizations. The agencies and or organizations with appropriate procedures supporting and increasing the work effectiveness of their employees tend to receive a good return on that investment and achieve rapid, effective, efficient and sustainable development, (Herman 1997).

In contrast, a lack of appropriate procedures in supporting and increasing the work effectiveness of internal employee results in employees being ineffective, apathetic and unable to achieve the desired satisfactory work performance (Santiwong, 1984).

In part as a response to research that challenged the effectiveness of traditional policing strategies, the 1980s and 1990s saw the emergence of a series of innovative police policies and best practices. They could be contrasted with the standard models of policing in earlier decades by their focus on taking an effective policing system approach to reduce the crime problems.

In recent years, to reposition the Nigerian Police Force, we have witnessed both a restructuring of the Police Force and a proliferation of 'Policing beyond the Police' as a result of which a more complex division of labour in the field of policing and security of the Nation has emerged, (Samuel, 1977).

Furthermore, the Nigeria Police Force is now recognized as part of a varied assortment of organization with policing functions and a diffuse array of effective policing processes with authority to enforce laws and distribute coercive force to achieve their goals (Adisa, 1999). 
Police effectiveness refers to the extent to which policing achieves its proper civic and officially sanctioned goals, (Sherman, 1986 \& 1997). However, consideration of police effectiveness turns out to be quite complicated for several reasons, including:

- $\quad$ The police have multiple goals, making their bottom line multi-dimensional;

- $\quad$ The relative priority of police goals is subject to discussion and debate among the public and within the police field, and

- $\quad$ Assessing police effectiveness is methodologically challenging.

Fortunately, these issues have gotten substantial attention in the police field since about the mid-20th century, and many effectiveness-oriented studies have been undertaken, These studies can be organized according to police practices (strategies, tactics, and programs) and desired effects (such as reducing crime, solving crime, and enhancing police legitimacy), (Kelling, 1978).

Although fighting crime and maintaining public order are two of the most important tasks of the government, our policymakers tend to have very limited information on how to achieve this goal. The political debate about the governments imperative 'to do something about crime' tends to revolve around a few readily available statistics like the strength of serving police officers, (Bayley, 1998).

After all, a straightforward way of signalling that fighting crime is a political priority is to channel more resources towards the police, to ensuring effective policing of the Nation as they are the most visible of public organizations that are supposed 'to protect and serve' us, (Booby 1829).

In this paper, we focus on efforts aimed at improving the efficiency and effectiveness of the Nigeria Police Force. That's the main point of these discussions, so far most of the literature focused on the constraints to police work. We, therefore, focus on what the police should do to improve the overall performance to ensure its effectiveness rather than on what the police should not do. Until recently, police had become synonymous with the activities of the modern professional police. In many senses, the development of the professional police was coupled with the information of the modern state. As a consequence, police came to be seen as a product of what the police do, (Zedner, 2006a).

\section{Conceptual Analysis}

\subsection{Meaning, Definition, Elements and Concepts}

The word police are related to the Greek words polite which means to be a citizen or engage in political activity, and polis, which also means a city or state, (Roberg \& Kuykendall, 2000). It also means to be a civil force of a state, responsible for the prevention and detection of crime and the maintenance of public order for the safety of the citizenry.

What we mean by the term as we consider the police system as in different societies, we mean by the police as an agency that could be distinguished in terms of the legitimacy, its structure, and its function.

By Legitimacy it implies that the police are granted some degree of monopoly within society by those with the power to so authorizes, whether this is an elite within the society an occupying power or the community as a whole. While, the structure we mean that the police are an organized force with some degree of specialization and code of practice within which, for example, legitimate use of force as specified in line with the codified laws and Acts of the country (Walker, 1977).

The extent of organization or specialization and the types of force considered appropriate will vary. Finally, function implies that the roles of the police is considered on law enforcement, order maintenance, service and gather information. Thus, the police are the major representatives of the legal system in their transactions with citizens. They are also the major emergency arm of the community in times of personal and public crisis management.

\subsection{Evolution and Development of Policing}

There is no-gain-saying that, the fundamental task of the police in all societies is to provide security and safety, through crime reduction, disorder, and fear of crime which is also one of the fundamental human needs (Maslow, 1970). However, in providing this, seeking the most effective ways to address the demands placed on the police, police organizations apply various approaches and concepts in fighting crime to the barest minimum (John \& Magaurine, 2006).

What must the police do to provide effective policing to $21^{\text {st }}$ century; first and foremost, it requires defining what constitute effectiveness in the term, which also provides a basis for understanding the discussions and findings, (Peterson, 2007)?

Therefore, effective policing is the result of many factors. It is dependent not solely on the activities or efficiency of the police, but also on the connection between the police and community they serve. Hence, effective policing requires both good policing outcomes and public support. So, policing outcomes, as indicated by crime rates, solving crimes and measures of the level of public order in society, are influenced by many factors other than policing (socio-economics, status, and individual characteristics), (Eck \& Rosebaum, 1999).

Firstly, the ability to achieve such outcomes will depend in part on how much support the public provides to the police. Secondly, even if the police judge policing outcomes to be successful according to formal measures of policing, public acceptance and recognition of these outcomes are needed for the police to be deemed effective by the citizenry they protect and serve, (Bobby, 1839).

Thus even if the crime rate is low overall a lack of trust or cooperation on the part, the public can mean that the police are perceived as being ineffective. This if either policing outcomes or level of support are judged to be insufficientfor any reason the police will likely be considered ineffective. 


\subsection{Objective of Policing}

The government's objective for the police can be defined in general terms as the reduction of crime, promotion of safety and reduction of disorder in an efficient, effective and fair and decent manner(Gau \& Travis, 2008). Efficiency is related to resource management. Therefore, working efficiently means allocating resources timely to places and times where they are most needed. While, effectiveness is related to identifying and implementing best practices, accountability and good policing. Hence, working effectively implies deploying resources in a way that they have the most impact. The imperative of fair and decent policing can be seen as a constraint to maximizing efficiency and effectiveness, (Eck \& Rosenbaum, 1994).

The rules of fair and good policing include limitations to the powers of investigations and the use of force and more informal rules such as providing courtesy in public contacts. These standards of conduct are constraints as they tend to slow down police work.

Without such constraints, police officers would search houses without a search warrant, seek out criminals without reading them their rights, allowing them to call their attorneys, or releasing them in response to a writ of ' habeas corpus'. Such police work would be efficient and effective, but it does not appeal to the idea of fair and decent policing.

\subsection{Policing}

Policing as a set of activities and processes is something that may be performed by a variety of professionals and ordinary people. This may be a group of professionals employed by the federal or state in a dedicated organization called 'the Police' with a broad mandate of crime control, management and order maintenance (John \& Spellman, 1987).

Besides, policing may be a task of professions employed either by (local or central)federal, state agencies with specialist policing functions, such as the regulation of particular types of crime or offense committed in a defined place, (Reiner, 2000)

Policing, on the other hand, refers to measures and actions taken by a variety of institutions and groups (both formal and informal) in the society (led by the Nigeria Police Force) to regulate social relations and practice in order to secure the safety of members of the public as well as compel them to conform to the norms and values the society expects of them.

However, Policing' is a function of governance responsible for the prevention, detection, and investigation of a crime; the protection of persons and property; and the maintenance of public order and safety.

\section{Theoretical Framework Analysis}

\subsection{Deterrence Theory (What- When \& How)}

The deterrence theory can be traced to the early works of classical philosophers such as Thomas Hobbes (15881678), Cesare Beccaria (1738-1794), and Jeremy Bentham (1748-1832). Together, these theorists protested against the legal policies that had dominated European thought for more than a thousand years, and against the spiritualistic explanations of crime on which they were founded. Also, these social contract thinkers provided the foundation for modern deterrence theory in criminology.

Therefore, there are two basic types of deterrence general and specific. General deterrence is designed to police and prevent crime and disorder in the general population. While specific deterrence is also designed by the nature of the proscribed sanctions to deter only the individual offender from committing that crime in the future.

The proponents of deterrence believe that people choose to obey or violate the law after calculating the gains and consequences of their actions. In addition to the enlightenment thinkers, (Zems, 2012) argues laws are made to either be obeyed or to be broken. Overall, however, it is difficult to prove the effectiveness of deterrence since only those offenders not deterred come to the notice of law enforcement. Thus, we may never know why others do not commit crime.

In the same vein, there are two related, theoretical perspectives that influence the study of crime and disorder policing include deterrence theory and opportunity theories. Deterrence theory posits that crime can be prevented if individuals believe the costs of committing a crime outweigh the benefits, (Zems, 2017, Zimring \& Hawkins 1973).

While, opportunity theories, such as rational choice theory, suggest that individuals weigh the costs and benefits of crime and choose targets that offer a maximum reward with minimal effort (Cornish \& Clarke, 1987). These theories are often used to guide some of the approaches to disorder policing, such as problem-oriented policing (Braga \& Weisburd 2010).

The most commonly used framework links changes in policing to changes in societal contexts. The policies change because the societies in which they operate change too. For example, changes in the ideologies and practices of policing throughout Nigerian history (the political, progressive/professional, and community policing models) resulted from factors such as public and intellectual disillusionment with the performance of prior models, leading to the legitimating of policing by large segments of society.

Therefore, theories of policing, largely comparative in nature, seek to explain why policing systems differ widely in their organization, the powers and authority granted them, the roles and tasks they are entrusted with, the occupational cultures that characterize their work, their interactions with civil society and the state, the quality and effectiveness of their work, the extent of entanglements in the political life of their societies, and their capacity to shape the dominant ideologies of policing that, in turn, define for themselves and for society what constitutes good and effective policing, (Walker, 1977)

Also, as an underlying subtext, theories include a normative element by linking the basic purposes and historical developments of policing to hegemonic notions of social control and social order and ideologies of justice in a society. 
Consequently, effective policing is a crime-control strategy that represents a shift away from the standard model of policing to a focus on signs of physical and social disorder in neighbourhoods. Concentrating on disorderly conditions, such as graffiti or loitering, is thought to send a signal to prospective offenders that illicit behaviour will not be tolerated. While crime and disorder policing do not rely on a single set of tactics, but a diversity of approaches and levels of focus (Weisburd \& Eck 2004). Some approaches involve the use of community-based or problem-oriented policing strategies.

Others involve the use of more aggressive order-maintenance or zero-tolerance policing strategies. However, the characteristic that unites these approaches is their focus on reducing neighbourhood crime and disorder as a mechanism for preventing or reducing crime. Thus, disorder policing can involve a wide variety of tactics, including arrests for misdemeanours (e.g., disorderly conduct, loitering) and citations or other code-enforcement measures for signs of physical disorder such as dilapidated buildings or black spot, (Siegel, 2005).

\section{An Overview of the Historiography of the Nigeria Police Force}

The history of policing in Nigeria today can trace its roots back to the colonial legacy. Therefore, pre-colonial experience, traditional African policing methods were rooted in the community and closely interlinked with social and religious structures. However, as the British sought colonial expansion across the territories known today as Nigeria, they established local, decentralized police forces. The first such force was created to police the Lagos colony in 1861. Subsequent constabularies were formed in what became the Northern and Southern Protectorates.

Colonial policies subjugated the existing traditional informal law enforcement order and forcefully imposed the western idea of policing. Thus, policing within the context of oppression and gross misuse of power has been linked to western orientation. This imperial orientation is not only maintained and sustained by successive Nigerian administrations but also have serious implication for an effective policing in Nigeria.

By contrast in the Northern Nigeria Protectorate, a system of indirect rule depended on the Hausa chiefs and emirs, and thus the emir's existing police system was strengthened. In 1930, the Northern and Southern Police forces emerged into the first national police force; called the Nigeria Police Force. This was headed by an Inspector General of Police (IGP).

The following years saw further changes in the organization of the force, such as the introduction of regional commands to reflect the federalism of Nigeria. Their responsibilities for maintaining law and order were now shared by federal and regional governments. When Nigeria became an independent country in 1960 from the British, the same basic structures were retained. Thus, the Independence Constitution (1960) and the Republican Constitution (1963) provided for Local Police Force and the Nigeria Police Force respectively.

In the year 1960, three innovative characteristics of police were established in Nigeria. They include:

- Firstly, Police was placed under the executive branch of the government.

- Secondly, Police were given uniforms to wear which made them immediately recognized and accessible to the public.

- Thirdly, and probably most importantly, the functions of policing were conceived to be proactive, to detect and prevent crimes, which included active patrolling in the community.

\subsection{The Force Historiography Timeline}

Nigeria Police Force was first established in 1820. The first person to have the highest rank in the entire police was Commissioner Gen. Colonel KK. In 1879, a 1,200-member armed paramilitary Hausa Constabulary was formed. In 1888, the Royal Niger Company set up the Royal Niger Company Constabulary. In 1894, a similar force, the Niger Coast Constabulary was established in Calabar. In 1896, the Lagos Police was created. In the early 1900s, part of the Royal Niger Coast Constabulary became the Northern Nigeria Police, of which the part of Niger Coast Constabulary became the Southern Nigeria Police. In the 1960s, under the First Republic, of Nigeria these forces were first regionalized and then nationalized.

\section{Role and Function of the Nigeria Police Force}

The Nigeria Police Force is a large agency of about 300,000 as a strength in the country established by law to provide security, having approximately 200 million citizens. In the (1979/199 constitution of Federal Republic of Nigeria) which provided for the establishment of Nigeria Police Force under section 214 (1) and section 4 of the Police Acts (laws of the federation 1990) as amended prescribed the role which includes:

- To uphold and enforce the law impartially, and protect life, liberty, property, human rights and dignity of the members of the public

- The protection and detection of crime/offense to reduce the opportunity for the commission of crimes.

- To protect public properties including Pipelines, NEPA, Railways, Bridge, critical installation and establishment against the act of vandalism, violence, or any kind of attacks.

- To protect internal security and prevent and control terrorists, banditry, militants activities and other situation affecting internal security

- To promote and preserve law and public order.

- $\quad$ Perform such military duties, etc.

Other role and function in which the Nigeria Police have more specific powers include:

- Conducting prosecutions before any court of law in Nigeria.

- Arresting, without a warrant, any person who is found by the police to be committing any felony, misdemeanour or simple offense; or who the police reasonably suspects of having committed those offenses or being about to 
commit such offenses. The Police may also arrest without warrant, a person who is charged by another person with the commission of an offense.

- It should be noted that where a specific offense provides that a person charged with that offense should be arrested with a warrant, then such alleged offender cannot be arrested without a warrant.

- The Police also have the power to search persons, premises, and belongings. On search of persons, where a police officer reasonably suspects any person of having in his possession or carrying in any form, anything which he has reason to believe has been stolen or is unlawfully obtained, the police officer may search and detain such a person.

- The police have the power to take and record measurements, photographs, and fingerprints of people who are in lawful custody from time to time. This is for identification.

\section{Factors Militating Against Police Effective Management and Control of Crime}

It is a known fact that in human endeavours, there are always problems inhibiting man's progress. The government too, has its problem of good governance, providing security for her citizens and maintenance of public order. Therefore, the Nigeria Police Force, in particular, being a very large organization has numerous teething problems and constraints within the force which impair the effective performance of its functions.

The major challenge facing effective policing in Nigeria is a deficiency in logistics supply. These include inadequate funding that arises from poor or inadequate budgetary allocations, manpower shortages, inadequate social infrastructure, inadequate arms and ammunition, inadequate Information and Communications Technology equipment and gadgets, lack of weaponry equipment, lack of operation patrol vehicles, among others.

The foregoing has since the flag of independence, remained the bane of public institutions in Nigeria. This is so because as the police are usually under-funded, they logically lack that much funds usually needed for intervening in addressing those ills that usually lead to effective crime control in society.

\subsection{Lack of Manpower Requirements}

Inadequate of working strength of Nigeria Police Force is militating against the effective performance of its statutory functions. Besides, factors such as retirement, withdrawals from service, death, dismissal, suspensions, and interdictions within the force, taken place without proportional replacement thereby creating more manpower shortfall.

This further, explains why officers are overstretched. The effect of this on the policemen is tiredness; tardiness and this turn out to breed indiscipline and inefficiency in their discharge of duties. This, of course, made it impossible for Nigeria Police Force to meet up the United Nations standard which stipulated that for a state to be properly protected it should be one policeman to four hundred civilians.

\subsection{Lack of Operational Vehicles}

The importance of vehicles in the daily performance of police functions cannot be overemphasized. The transport branch of the Nigeria Police Force was established in the 1950s to take care of daily transport operation of force. Thus vehicles are of paramount importance, to the force, for conveying policemen to beats, patrol duties, quelling of riots/unlawful assembly, investigations, conveying of suspects to court for prosecution of cases, and transferees, for movement of staff and materials, etc.

If they exist, they may be unserviceable vehicles. Consequent upon this, the heads of departments and divisional police officer would carry-out the burden of repairing such vehicles with resources from no-where which invariably breeds corruption in an attempt to keep the vehicles on the road to combat crime.

It is disappointing too that, in the event of such situations, police operation is made ineffective in the administration of justice, as complainants are required to provide a vehicle for a visit to the scene of the crime, arrest of suspects, and conveyance of suspects to courts and accused person to prison custody. Ordinarily, this is not supposed to be so, but the contrary is the case because there are no serviceable operation vehicles for effective policing.

\subsection{Insufficient Funding}

This has been one of the greatest problems, the insufficient funding of the Nigeria Police Force by the past and the present government has been a major problem inhibiting the effective performance of its statutory functions. To have an efficient, effective, standard model and reliable security organization, the world over, it is capital intensive. During the military era, there was a deliberate act to underfund the Nigeria Police Force over the years, probably to make the Police Force subservient to the military.

The effect of this is that all the types of equipment, infrastructures (forces headquarters/state headquarters buildings/ police stations/barracks schools/colleges/Academy) got rusted, dilapidated and this impaired effective management and performance of the police administrative duties, including crime control.

\subsection{Poor Welfare on the Personnel}

In Nigeria, it is no longer an issue that the current welfare situation of the officers of the Nigeria Police Force constitute an impediment to effective performance with regards to law enforcement in the current democratic dispensation and calls for urgent improvement to enable the agency to continue to contribute meaningfully to safeguarding the nascent democratic system existing in the country. The poor welfare of the Nigeria Police Officers are such concerns as the deplorable housing, non-existing or inferior medical services, badly maintained weaponries, emolument, non-payment of allowance, no viable life insurance scheme, the ragged uniforms and the generally poor conditions of service. 


\section{Factors Influencing Effective Police Performance}

They include the following:

\subsection{Democratic Policing}

Today's ideal is 'democratic policing.' This means, broadly, a police force that is publicly accountable, subject to the rule of law, respectful of human dignity and that intrudes into citizens' lives only under certain limited circumstances. Its mechanism is established by the government to protect people's rights, freedom, and maintain law, order and guarantee stability and security of a country are usually referred to collectively as the security agent or sector, (Travis1998). The important factor in such security sector is called the 'POLICE', whose roles and functions as a minimum, include:

- To preserve tranquility, law, and order

- Prevention and detection of crimes

- Protects a life, liberty, and property of the people.

To carry out these functions, the police have certain powers, namely the power to

arrest and detain and the power to use force. It is precisely this monopoly on the use of force and the power to arrest and detain that place the police in a unique and sensitive position within the democratic settings so that adequate control mechanisms are required to ensure that these powers are consistently used in the public interest. Like any other public service, the police must operate with impartiality. In otherwords, good policing is policing that is effective, efficientand fair. Police who are ineffective, or illegitimate or unfair, in protecting the public against crime will lose the public's confidence. Good policing is also policing with legitimacy based on public consent, rather than repression. Therefore, achieving public confidence is key to effective policing where police functions can be carried out based on legitimacy rather than force (Jacinta \& Pratt, 2008). Furthermore, good policing requires public cooperation, members of the public may be witnesses and victims of crime, and they can provide the police with relevant and timely information. Therefore, enhancing police accountability and integrity is primarily meant to establish, restore or enhance public trust and rebuild the legitimacy that is prerequisite for effective policing.

\subsection{Intelligence-Le-Policing}

Intelligence-led policing is considered an optimal option for fighting crime to stand still. Central to Intelligence-led policing is law enforcement officers partnering with the communities in terms of sharing intelligence information and responding to crimes, (Zems, 2013).

'Intelligence-led policing is an approach to effective policing that turns away from the traditionally reactive style used in the past to a proactive framework that focuses on employing analysis and criminal intelligence to reduce crime and to combat prolific recidivist offenders (Ratcliffe, 2009, p177). Although considered to be a style of 'policing', intelligenceled policing is essentially a business model where intelligence permeates through all areas of law enforcement, both tactically and strategically (W.A. Police Intelligence Model, n.d., p3).

Intelligence-led policing is a model of policing in which intelligence serves as a guide to operations, not the reverse (Smith, 1997, p1). Sources of intelligence are gathered from informants, offenders, analysis of existing crime records, covert surveillance and community sources (Ratcliffe, 2009, p176). Once the intelligence from these sources has been analyzed, decisions regarding objective policing tactics, prevention operations, and further intelligence-gathering operations can be undertaken with greater precision (Ratcliffe, 2009, p176).

\subsection{Standard Model of Policing}

The standard model strategies are often seen as traditional police approaches to dealing with a crime that developed largely during the reform or professional era beginning around the 1930s (Kelling \& Moore, 1988).

In today's climate, there are a lot of misgivings about law enforcement, and the way that it is carried out. There have been tensions between certain elements and the police throughout history, but now age is being entered of even more public outrage than what has come to be considered 'the norm'. Some of the issues that have arisen are specific to individuals, some to particular police departments, but others are institutional. The types of standard model policing include:

- Random Patrol Across all parts of the Community

- $\quad$ Rapid Response to Emergency (Emergency calls 911)

- Generally Applied Intensive Enforcement and Arrest Policies.

\subsubsection{Generalized Investigations of Crime}

In light of these issues, it becomes necessary for people to analyze the various methods of policing that have developed, and how they compare to the standard model of policing. An analysis needs to be done of the alternative methods of policing, and their effectiveness in crime prevention. Starting by describing what is known about the standard model and comparing it to these other methods, information can be gleaned as to what changes need to be made in modern-day law enforcement to increase effectiveness.

However, the standard model of policing is exactly as its name implies, it sets the standard for effective policing across the country. It is what one tends to envision when one thinks about what policing is. It consists of random patrols through streets, in hopes of creating a feeling that police can be anywhere at any time and an increase in officers to attempt to catch more crimes in the process. 
These officers are trained to quickly respond to service calls to attempt to apprehend criminals before they make their escape, among other reactive techniques. When crimes have already been committed and more evidence and information is needed, then officers will follow up with the parties involved to glean further knowledge and heighten the likelihood that a crime will be solved (Santos 2012).

\subsection{Community Policing}

Community policing is a philosophy of full service personalized effective policing, where the same officers patrols and works in the same area on a permanent basis, from a decentralized place, working in a proactive partnership with citizens to identify and attack crime, (Alemika \& Chukwuma, 2000). It promotes and supports organizational strategies to address the cause and reduce the fear of crime and social disorder through - solving tactics and police-community partnership (Keeling, 1988).

Quite recently, there has been a growing desire within communities to participate in the fight against crime and disorder which has, of course, paralleled a growing trend forwards recognition by the police that their crime-fighting tactics alone have a limited impact on controlling crime, (Skogan, 2006).

Community policing is, therefore, a synthesis of these two trends. Community policing has been simply defined as a deliberate attempt at combining the efforts, capacities, and resources of the police and those of the community being policed to forge a common force aimed at controlling and preventing crime and disorder through partnership and problem-solving approaches (BJA, 1994)

This assumes a need for greater accountability of police, greater public share in decision making, and greater concern for civil rights and liberties. 'Community policing is democracy in action'. It requires the active participation of local government, civic and business leaders, public and private agencies, residents, churches, mosques, schools, hospitals, etc.

\subsection{Problem-Oriented Policing}

Problem-oriented policing converged on three main themes: increased effectiveness, reliance on the expertise and creativity of officers, and closer involvement with the community. These themes become a reality by attacking underlying causes that deplete patrol officers and detectives' time, and educating officers to study problems and develop innovative solutions to ensure that address the needs of citizens, (Eric,1992).

It is a policy and strategy aimed at achieving more effective and efficient crime control, improved quality of life, improved police service and police legitimacy, through a proactive reliance on community resources that seeks to change crime causing conditions., (Herman,1990).

POP represents police-led efforts to change the underlying conditions at hot spots that lead to recurring crime problems. It also requires police to look past traditional strategies and consider other possible approaches for addressing crime and disorder effectively, (Weisburd \& Eck 2004). Today, it is one of the most widely used strategies among progressive law enforcement agencies for effective policing (Weisburd et al. 2010).

The POP theory is referred to as Scanning, Analysis, Response, and Assessment (SARA) - refers to four key steps in the problem solving and decision making processes:

- Scanning involves looking for patterns of problem activities, including victims, locations, and types of crimes. It requires an evaluation of the problem, the perception of the problem by both law enforcement and external partners, and an analysis of the severity of the problem.

- Analysis, which includes looking for the root causes of any problems or issues identified. Information is gathered from a variety of sources, including crime reports and community members who are directly affected by the issue. Causes of problems can include many factors, including neighbourhood and community perceptions of law enforcement themselves.

- Once the cause is identified, law enforcement officials will work with the community to come up with and execute an appropriate, long-term response. After the response is implemented, an ongoing assessment is required to evaluate the effectiveness of the solution and make adjustments as appropriate.

\subsection{Proactive Policing}

In the year 1970, proactive policing takes on a variety of meanings. In the most general sense, it is the polar opposite of reactive which is characterized by randomized patrol, rapid response to calls for service, and retrospective investigations. Instead of waiting for a crime to transpire, proactive policing entails striving to prevent crime before it ever comes to fruition. Strategically, the police can go about accomplishing this goal in several ways. Several of the most prevalent philosophies are described below.

The first section distinguishes between aggressive 'broken windows' policing and problem-oriented strategies. In the sections that follow, key readings have presented that highlight the evidence for and against both models. From there, the discussion turns to hot spots proactive policing philosophy that certainly aligns with the problem-oriented approach but worthy of separate consideration, (Bundy 1970; Kelling \& Coles 1996;)

As proactive police strategies have gained momentum throughout the last few decades, technology has become more sophisticated, which facilitates inter- and intra-agency communication as well as identifying problems within a community. Consequently, a section is devoted to advances in technology and software.

Finally, pair of techniques that encourage proactively and have become very popular in recent years are offered: predictive police and social network analysis. The models and techniques presented here are not meant to be an 
exhaustive list of proactive police strategies. Instead, they represent some of the most prevalent approaches. Collectively, this research makes it abundantly clear that proactive policing is a broad concept that includes a variety of different approaches, (Weisburd\& Braga 2006).

\subsection{Policing, by Third Party}

The major premise of third party policing is that police on their own cannot succeed in reducing many crime and disorder problems. Instead, they need to draw on the social control mechanisms held by other government and community actors. Third-party policing occurs when police leverage other the powers or legal levers held by those other actors or partners to help control or reduce crime or disorder. The move for police to work through partners has accelerated due to trends in governance, the increasing scope of government regulation, and the expectation that communities will help co-produce public safety, (Buerger \& Mazerolle, 1998).

At a time when many police agencies face budget restrictions, encouraging others to assume some crime control responsibility becomes especially important. These trends have expanded how crime can be regulated and prevented in ways that do not rest only on traditional criminal law or justice processes. Typical police partners include regulators, businesses, property owners, and schools. Legal levers include property or fire codes, liquor regulation, rental contracts, and school suspension or discipline powers. (Weisburd \& Green, 1995). (Braga, Papachristos, \& Hureau, 2010; Eck, Gersh, \& Taylor, 2000),

Police seek to activate or escalate their partners' use of these non-criminal powers, either cooperatively or coercively, to extend the range of policing influence over problem places, people, or situations. Therefore, third party policing is both proactive, i). in that it is focused on addressing and reducing the causes of crime and disorder, and problem-oriented, ii). in that it seeks to do so by analyzing and resolving recurrent, underlying problems. The focus on places, people, and situations also aligns with situational crime prevention techniques, such as hotspots policing and focused deterrence, (Mazerolle \& Ransley, 2005).

But third party policing is differentiated from these other approaches through its reliance on the legal levers of partners. The first section in this entry outlines how third-party policing has developed over the past twenty years. There are also sections on the role and use of regulation in policing, the contribution of civil remedies to crime prevention, descriptions of the multiple contexts in which third party policing has been adopted, factors that promote successful partnerships, assessments of outcomes and effectiveness, and issues to do with ethics and accountability, (Weisburd \& Mazerolle, 2000).

\section{Conclusion}

By strengthening our democracy, with a particular emphasis on the human rights of all community members, in particular, the most vulnerable ones, community-oriented policing is developing, which a shift from traditional in policing Nigeria. This means that it leads to changes in the functioning of the police in a way that the Nigeria Police, in addition to its traditional control function, has also acquired a proactive role for effective policing in contemporary Nigeria.

Consequently, the numerous impediments to effective policing in contemporary Nigeria be considered and seriously tackled to enhance the functionality of the alternative to the traditional policing which has provided limited success.

Furthermore, comprehensive and continuous training and retraining are most needed to provide a new orientation to the Nigeria Police to cope with the modern challenges of a high degree of social disorder in the country.

Finally, when it concerns of good policing, governance and best practices in a nation and society at large context, we must take all relevant realms of effective policing into account. However, in this paper, we have been able to identify key indicators and factors of effective and efficient policing practices.

\section{References}

i. Adisa, J. (1999) ' A New Nigerian Police Image: Its Role in the Next Millennium' Text of a lecture delivered at a seminar organized for Assistant Inspectors General and Commissioners of Police by the Nigeria Police Force at the International Conference Centre Abuja, October 19-20.

ii. Akers, R. L. (2000). Criminological theories. Los Angeles: Roxbury. Andenaes, J. (1974). Punishment and deterrence. Ann Arbor: University of Michigan Press.

iii. Alemika, E. and Chukwuma, I. (2000) Police-Community Violence in Nigeria, Lagos: Centre for Law Enforcement Education.

iv. Alemika, E.E.O. (1993). 'Colonialism, State and Policing in Nigeria' Crime, Law and Social Change (20) 187-219.

v. Alemika, E.E.O. (1999) 'Police-Community Relations in Nigeria: What Went Wrong?' in I. Chukwuma and I. Ifowodo (eds). Policing a Democracy, Lagos: Centre for Law Enforcement.

vi. Beccaria, C. (1963). On crimes and punishments (introduction by H. Paolucci, Trans.). New York: Macmillan. (Original work published 1764)

vii. Bentham, J. (1948). An introduction to the principles of morals and legislation (with an introduction by W. Harrison, Ed.). New York: Macmillan.

viii. Binet, Alfred (1916) [1905]. 'The Development of Intelligence children: The Binet-Simon Scale. E.S. Kite (Trans). Baltimore Williams \& Wilkins.Pp.37- 90. University of Michigan Library, USA.

ix. Braga, Anthony A., and David Weisburd. 2010. Policing Problem Places: Crime Hot Spots and Effective Prevention. New York: Oxford University Press.

x. Brand., S. G. (1993), 'The Impact of Case Characteristics on Detectives' Decision Making'. Justice Quarterly 10. 
xi. Cordner, Gary. 1998. 'Problem-Oriented Policing vs. Zero Tolerance.' In Tara O'Connor Shelley and Anne E. Grant (eds.). Problem-Oriented Policing: Crime-Specific Problems, Critical Issues, and Making POP Work. Washington, D.C.: Police Executive Research Forum, 303-314.

xii. Cornish, D., and R. V. Clarke. 1987. 'Understanding Crime Displacement: An Application of Rational Choice Theory.' Criminology 25: 933-47.

xiii. Eck, J. E., \& Rosenbaum, D. P. (1994). The new police order: Effectiveness, equality, and efficiency in community policing. In D. P. Rosenbaum (Ed.), The challenge of community policing: Testing the promises (pp. 3-23). Thousand Oaks, CA: Sage.

xiv. Eck, John E. and William Spelman (1989), 'A Problem-Oriented Approach to Police Service Delivery'. Police and Policing: Contemporary Issues, ed. Dennis Jay Kenney. New York: Praeger.

xv. Eck, John E., and William Spelman et al., (1987) Problem Solving: Problem-Oriented Policing in Newport News, Washington. D.C: Police Executive Research Forum. Pp xvi-xvi. See also, Clarke. Ronald V. 'Situational Crime Prevention: Its Theoretical Basis and Practical Scope Crime and Justice: An Annual Review of Research eds Michard Tony.

xvi. Eck, John E., and Edward R. Maguire. 2006. 'Have Changes in Policing Reduced Violent Crime? An Assessment of the Evidence.' In Alfred Blumstein and Joel Wallman (eds.). The Crime Drop in America, Second Edition. New York: Cambridge University Press, 207-65. Gau, Jacinta M., and Travis C. Pratt. 2008. 'Broken Windows or Window Dressing? Citizens'(In) Ability to Tell the Difference between Disorder and Crime.' Criminology \& Public Policy 7(2):163-94. Goldstein, Herman. 1979. 'Improving Policing: A Problem-Oriented Approach.' National Probation and Parole Association Journal 25(2): 236-58.

xvii. Flanagan, R. (2008a). The review of policing: Final report. Surrey, UK: Police Federation of England and Wales.

xviii. Hinkle, Joshua C., and David Weisburd. 2008. 'The Irony of Broken Windows Policing: A Micro-Place Study of the Relationship between Disorder, Focused Police Crackdowns and Fear of Crime.' Journal of Criminal Justice 36(6): 503-12.

xix. Kelling, George L., and William H. Sousa. 2001. Do Police Matter? An Analysis of the Impact of New York City's Police Reforms. New York: Center for Civic Innovation at the Manhattan Institute. Skogan, Wesley G. 2006. Police and Community in Chicago: A Tale of Three Cities. New York: Oxford University Press. Weisburd, David, and John E. Eck. 2004. 'What Can Police Do to Reduce Crime, Disorder, and Fear?' The Annals of the American Academy Political and Social Science 593: 42-65. Wilson, James Q., and George L. Kelling. 1982. 'Broken Windows.' Atlantic Monthly 249(3): 29-38. Worrall, John L. 2002. Does 'Broken Windows' Law Enforcement Reduce Serious Crime? Sacramento, Calif.: California Institute for County Government. Zimring, Frank, and Gordon Hawkins. 1973. Deterrence: The Legal Threat in Crime Control. Chicago, Ill.: University of Chicago Press.

xx. Marenin, O. (1985) 'Policing Nigeria: Control and Autonomy in the Exercise of Coercion' African Studies Review 28 (1)

xxi. Mastrofski, S., (2006) 'Critic - Community Policing: A Sceptical View' in Police Innovation: Contemporary Perspectives, ed. D. Weisburd, and A. Braga, Cambridge University Press: Cambridge, pp 44-73

xxii. Walker, Samuel (1977) A Critical History of Police Reform: The emergence of professional. Lexington. MT. Lexington Book pp143 ISBN 978-866901292-7.

xxiii. Zems M (2013) Understanding Crime: Analysis for Intelligence, Investigation, and Security: (Key issue in Criminology') $1^{\text {st }}$ (ed) Guaganzhou Quick Printing Co ltd China.

xxiv. Zems, M. (2017) Understanding Principles and Practice of Crime and Criminology (Tomorrow's Research Today') Create-Space Printing Ltd, Lexington, KY, Uni 